This item was submitted to Loughborough's Research Repository by the author.

Items in Figshare are protected by copyright, with all rights reserved, unless otherwise indicated.

\title{
Market performance - liquidity or knowledge? Evidence from the market for corporate control
}

PLEASE CITE THE PUBLISHED VERSION

https://www.routledge.com/Theory-and-Method-of-Evolutionary-Political-Economy-A-Cyprus-

Symposium/Hanappi-Katsikides-Scholz-Wackerle/p/book/9781138204096

\section{PUBLISHER}

(CTaylor \& Francis (Routledge)

\section{VERSION}

AM (Accepted Manuscript)

\section{PUBLISHER STATEMENT}

This work is made available according to the conditions of the Creative Commons Attribution-NonCommercialNoDerivatives 4.0 International (CC BY-NC-ND 4.0) licence. Full details of this licence are available at: https://creativecommons.org/licenses/by-nc-nd/4.0/

\section{LICENCE}

CC BY-NC-ND 4.0

\section{REPOSITORY RECORD}

McCarthy, Killian J., and Wilfred Dolfsma. 2019. "Market Performance - Liquidity or Knowledge? Evidence from the Market for Corporate Control”. figshare. https://hdl.handle.net/2134/23020. 


\title{
MARKET PERFORMANCE - LIQUIDITY OR KNOWLEDGE? EVIDENCE FROM THE MARKET FOR CORPORATE CONTROL
}

\author{
Killian J McCarthy ${ }^{\text {A* }}$ \& Wilfred Dolfsma ${ }^{\mathrm{B}}$ \\ ${ }^{\mathrm{A}}$ University of Groningen School of Economics \& Business, The Netherlands \\ ${ }^{B}$ Loughborough University London, London, UK
}

A key term in economics, the exact definition of what a market is remains hotly debated (cf. Rosenbaum 2000). Markets, economists insist, are physical or virtual places where supply and demand meet to determine prices. Theory suggests that in more liquid markets deals are concluded that are more attractive to both the selling and the buying party than in less liquid markets. At the same time, as suggested by management scholars, especially for markets where complex goods are traded, a market also is a location where relevant knowledge coalesces. In a market where more relevant knowledge is available, better performing deals are concluded. For the purpose of our study, markets may best be defined as defined markets as "institutionalised exchanges, where a consensus over prices and other information may be established” (Hodgson 1999, p.269). We study a market in which complex goods are traded: firms themselves. This is the market for corporate control. More liquid markets are markets where more deals are concluded, thus markets with what in network theory is called a high degree centrality (Freeman 1978-9). Markets where much knowledge is available are markets with what in social network literature is called a high betweenness centrality (Freeman 1978-9). We use Thomson Reuter SDC data on mergers \& acquisitions to determine which of these effects is biggest (cf. Fuller et al. 2002). The results we have suggest a richer understanding of the functioning of markets is needed.

\section{LITERATURE}

Markets are physical or virtual places in which parties voluntarily exchange specific goods. The exchange can and often does involve a general medium of exchange such as money, but need not do so. While the exchange can involve actions in the (distant) future, and thus need not be a quid pro quo, and an exchange can involve some degree of uncertainty about what is exactly exchanged, the parties should know to some degree what the exchange involves.

\footnotetext{
* Contact: Killian J McCarthy, University of Groningen School of Economics and Business, Nettelbosje 2, 9747 AE Groningen, the Netherlands. Email: k.j.mccarthy@rug.nl. Tel +0031503636810
} 
Classically, in economics, markets are said to function well in one of two circumstances.

The textbook argument states that in markets that are liquid, supply and demand meet more readily. In liquid markets, markets in which more deals are done, specifications of what is offered for sale by sellers are more likely to be what potential buyers are looking to buy. Because of this, more and more diverse deals are done - diverse in terms of deal sizes, for instance. Because buyers are more likely to find what they are looking for, not having to settle for a less attractive good, they are willing to pay a higher price. Deals done in textbook economics 101 type markets are likely to be better deals.

The Austrian economics argument about well-functioning markets draws on Friedrich Hayek's 1945 article about the role of knowledge on markets. Markets where more relevant knowledge is available about potential deals to be made, are markets where better deals are done. Hayek was involved in a discussion with the likes of (...) about the question if markets could be directed by government. Hayek claimed that they could not because there was more knowledge required to do so than a government could handle, that some of would necessarily be locally stuck, and that the market process < generated> knowledge instantaneously itself. Knowledge inheres in markets.

Economic activities typically involve two, and possibly more, partners who voluntarily do a deal. Partners doing a deal can be seen as connected through the deal they strike. Partners are each based somewhere geographically, but a deal can be done between partners who are located in different locations. If they are, there can be said to be a connection between these locations. Locations can in that sense be seen as markets, a view certainly consistent with how economists originally conceptualise markets (Zuidhof 2014).

Markets in which more deals are struck, inside or with partners based outside of it, are more active or liquid markets. The economics 101 explanation of what makes markets function well would expect deals being done in such markets to do better than deals being done in less active or liquid. Assuming that indeed knowledge is generated in markets as deals are done, and that knowledge about markets, possible players in the market, and how to do deals best spread through market processes, knowledge about markets spreads as deals are done between players in different locations. Social network analysis (SNA) allows for an analysis about how knowledge spreads through a network of interconnected locations in which players are active (Freeman 1978-9; Aalbers \& Dolfsma 2015). From the perspective of SNA, partners doing deals from a particular location can be viewed in the aggregate as a node in a network connecting to partners in another location that in turn can be viewed in the aggregate as a node. Nodes for our purposes are markets where market players are based. Relations or ties between nodes are formed by the deals done between partners in a location (market).

The Austrian view of markets can thus be operationalized by translating it in terms akin to those in Social Network Analysis. This view can then be said to predict that markets in which players are active that are centrally placed between other markets through the deals made in the overall market connecting all 
individual markets should be expected to do better than less well connected market nodes. This effect should be independent of the total size of the markets deals taking place in that market in total.

Hyp.1: More liquid markets, i.e. markets in which more players conclude deals, show better deal performance than less liquid markets.

Hyp.2: Markets in which more relevant knowledge is available show better deal performance than markets in which less relevant knowledge is available.

Market for corporate control. The market for corporate control is the market in which ownership in companies is traded. Trades done in this market are complex, highly dependent on regulation in place, keenly future oriented, and concluded by exceptionally highly knowledgeable players. In this knowledgeintensive market, the types of deals concluded, if not the type of deals considered by players, are diverse. Knowledge thus appears to be an important ingredient for performance of deals done, but also the likelihood that supply and demand preferences and conditions are met with. The latter indicates that a deals done in a more liquid market should be expected to do well.

The major form deals in the market for corporate control takes is that of Mergers \& Acquisitions (M\&As). In case such deals cross borders, this is referred to as Foreign Direct Investment (FDI), and constitutes a large part (..\%) of this market closely watched by governments. At the height of activities in this market, which comes in waves (Mccarthy et al. 2016), some xxbn\$ worth of deals are concluded. As a result of this, the market for corporate control is an important indicator of how markets in general can be assumed to function (cf Mccarthy \& Dolfsma 2015).

\section{METHODS}

Data. We use Thomson SDC to build our sample of mergers and acquisitions. We refine this to include all deals between January 1, 1990 and December 31, 2012, which do not involve a recapitalization, repurchase of own shares, or a spin-off to existing shareholders. We only include deals for more than 10 million US\$, announced by publicly listed acquirers, in which the location of both the target and the acquiring firms were reported. We exclude which involve the public authorities, such as the U.S. government, and all deals in which the acquirer and the target are part of the same group. Doing so, we create an initial sample of 35,709 mergers and acquisitions. Figure 1 illustrates the geographic spread of the 35,709 acquiring firms in our sample. 


\section{FIGURE 1}

Centrality. Centrality can be measured in a number of different ways (Opsahl et al., 2010). The simplest measure of centrality -- degree centrality -- considers the number of ties that each node in the network possesses, compared to the total size of the network. Degree centrality, therefore, is the classic centrality measure, as it simply counts the number of ties between nodes. Betweenness centrality, by contrast, is a measure of the number of times a node is included on the shortest path between other nodes in the network. Betweenness centrality, therefore, considers the degree to which a node is important in bridging nodes (e.g., Gilsing et al., 2008). We calculate both measures, given that both measures capture different elements of network centrality.

Performance. We measure deal performance using a market-adjusted event study (Brown \& Warner, 1980; 1985; Fuller et al., 2002; Schoenberg, 2006; Papadakis and Thanos, 2010; Gregory et al., 2013). This technique is, today, the most commonly employed measure of acquisition performance in the strategic literature (King et al., 2004; Zollo and Miere, 2008; McNamara et al., 2008).

An event-study is a tool used for assessing the way in which an event - such as an acquisition - causes a change in the value of a firm (Brown \& Warner, 1980; 1985). In an event study, historical data is used to forecast 'normal' performance at a future date. Comparing this 'forecast' of how the firm should have performed -- in the absence of an event -- with 'actual' data on how the firm performed -- in the presence of the event -- provides an indicator of the firms 'abnormal' return; this is the change in value, above or below the firm's expected value, attributable to the event. The sum of the acquirer's abnormal returns (ARs) in a predefined period of time (the 'event window') is referred to as the cumulative abnormal returns (CARs). More specifically, we calculate the firms abnormal return of firm i;

$$
A R_{i, t}=R_{i, t}-E\left[R_{i, t}\right]
$$

Where $R_{i, t}$ is the actual return and $E\left[R_{i, t}\right]$ is the estimated or normal return (Brown \& Warner, 1980; 1985; MacKinlay, 1997; Duso et al. 2010). Normal returns are then calculated as:

$$
E\left[R_{i, t}\right]=\alpha_{i}+\beta_{i} R_{m, t}+\varepsilon_{i, t}
$$

Where $\alpha_{\mathrm{i}}$ is the intercept coefficient, $\beta_{\mathrm{i}}$ is the slope, $\mathrm{R}_{\mathrm{m}, \mathrm{t}}$ the formation of the used benchmarks, and $\varepsilon_{\mathrm{i}, \mathrm{t}}$ is expected to be equal to 0 (MacKinlay, 1997). The abnormal returns in the event window are added, to create the cumulative abnormal returns (CAR) to the firm as:

$$
C A R_{i}\left[t_{1}, t_{2}\right]=\sum_{t=t_{1}}^{t_{2}} A R_{i, t}
$$

Strategic management studies often use accounting-based measures of acquisition performance, such as return on assets (e.g., Ramaswamy, 1997). Cumulative abnormal returns (CARs) are thought to be the more 
appropriate measure because: (1) the event study methodology (and, hence, cumulative abnormal returns) is the most frequently used analytical approach for measuring acquisition performance (e.g., Capron \& Pistre, 2002; King et al., 2004; Zollo \& Miere, 2008; McNamara et al., 2008); (2) acquisition effects are not immediately reflected in the financial statements of an acquirer, because it often takes six months to three years before the acquirer realizes the effects (Rhoades, 1994), and during this period, many confounding factors, such as changes in product mix, investment strategy, and management, as well as execution of additional acquisitions, may affect firm performance; (3) accounting-based performance measures can be misleading because accounting procedures are not uniform across firms and industries (Bentson, 1985); and (4) research has shown that ex ante measures of acquirer abnormal returns are highly correlated with ex post measures of acquisition performance, demonstrating that event study methodology has predictive validity (Healy, et al, 1992).

Following the practice in the literature, we compute abnormal returns to the shareholder of the acquiring firm using a number of different event windows (see Martynova and Renneboog, 2008 for a review). We calculate: a $(+1,-1)$ CAR, from 1 trading day before the announcement to 1 day after (CAR1); a $(+1,-2)$ CAR, from 2 trading days before the announcement to 1 day after (CAR2); a (+1,-5) CAR, from 5 trading days, or one week before the announcement to 1 day after (CAR5); and a $(+1,-20)$ CAR, from 20 trading days, or four weeks, or one month, before the announcement to 1 day after (CAR1). It is standard practice to include the period prior to the announcement in the estimation to capture the effect of rumours and information leakages, which drive up the firms share price, in anticipation of future performance gains (Schwert, 1996). In order to remove the effect of outliers, we winzorised all CARs between 1 and 99\%. Data limitations, at this point, reduces the sample of acquisitions for which we could calculate performance from 35,709 to 19,273 . We drop the remaining deals from our analysis.

\section{TABLE 1}

Controls. A number of acquirer-, target-, and deal-specific characteristics are known to impact the way in which the market responds to the announcement of a deal (see e.g., King et al., 2004).

We control for: (1) the Percent Acquired, in terms of how much of the target the acquirer purchases, because deals for less than 100\% often run into more difficulties in the integration phase; (2) acquirer's Financial Slack - which we define as the acquirer's operating cash flow, normalized by total assets over the last four quarters before the announcement - because Jensen (1986) suggests that financial slack predicts sub-par acquisition performance; (3) the Acquirers Prior Performance $\mathrm{r}$ - which we estimate as the acquirers return on assets the year before the acquisition - because research shows that prior performance predicts future performance (Morck et al., 1990); (4) Acquirer Market-to-Book Ratio - which is a ratio of the acquirers market value to its book value - because Rau and Vermaelen (1998) show that market-to-book ratios predict acquisition behaviour and performance; (5) Relatedness - which we identify using an indicator 
variable set equal to 1 if the target and acquirer share the same primary two-digit standard industrial classification (SIC) code - because research related acquisitions outperform unrelated acquisitions (Chatterjee, 1986); (6) Cross-border deals - which we identify with a dummy set equal to 1 if the target and the acquirer are from different countries - because the international business literature is premised upon the suggestion that international borders imply costs.

The data to construct these variables was collected from Datastream. Table 1 reports the correlation and descriptive statistics for our key variables. We winsorized each of the control variables, between 0.05 and 99.5\%, to remove outliers. We test each of the controls for normality, using a Shapiro-Wilk test, and employed the logs of any variables (Acquirers Financial Slack, Acquirers Prior Performance,) which failed this test when entering these in our model.

Estimation. We estimate the impact of centrality on performance using standard OLS regression techniques. We control, in all estimates, for unobserved effects by including: (1) year dummies; (2) industry dummies for the acquirers and targets industry, using each firm’s 2-digit SIC codes

\section{RESUlts}

We estimate 8 OLS regression models. Tables 2 and 3 report the results. Table 2 reports 4 OLS models in which the independent measure is betweenness centrally. The models differ in the dependents that they use: Models 1 uses the winsorized CAR of the firm in the $(+1,-1)$ window (CAR1), Model 2 use the winsorized CAR of the firm in the $(+1,-2)$ window (CAR2), and so on. All four models are consistent, and suggest that the betweenness centrality of the acquiring firms location has a negative and significant impact on deal performance.

\section{TABLE 2}

Table 3 reports this exercise, using degree centrality as the independent centrality measure. Again, the four models present a consistent story: Models 5-8 report that the degree centrality of the acquiring firm's location has a negative and significant impact on deal performance.

\section{TABLE 3}

The relatively low r-squared in each case - between 3\% and 9\% -- is typical of event studies. For example: Moeller et al. (2005) use an event study, and OLS estimation, to investigate the performance of 6,596 mergers and acquisitions, and report adjusted R-squares of 2.4-5.6\%; Morck and Yeung (1992) use an event study, and OLS estimation to investigate the announcement of 322 internationalisations, and report Rsquares of 0-4.3\%; Muller and Kräussl (2010) use an event study, and OLS estimation, to study the announcement of 354 corporate disaster donations, and reports adjusted R-squares of 4-6\%; and McNamara and Baden-Fuller (2007) use an event study, and OLS estimation, to investigate the returns to R\&D 
announcement by biotechnology firms, and report R-squares of 1-7\%, using a sample of 180 firms. As our results fit within these window, we can be confident as to the goodness of fit of our model.

\section{CONCLUSIONS}

Markets are suggested to work well in economics if they are either (1) liquid in the sense of relatively many suppliers and buyers seeking to do deals, or (2) well stocked with knowledge. The first view is related to textbook economics, while the last is connected with the Austrian view of economics and in particular with Friedrich Hayek. Empirically, these views can be captured using social network analysis of deals done in the market for corporate control (M\&As). As we explain at length in the method section, deals connecting locations where target or acquirer are based constitute networks; locations with a high degree centrality are liquid, and locations with a high betweenness centrality are locations where much knowledge is accumulated. Assuming that our assumption of the market for corporate control being a proper indicator of how markets function is a correct one, the results we are able to present are a cause for further consideration of how exactly markets actually work. We find that neither do well, contrary to expectations.

Much more seems to be involved than liquidity in a market and players, generally being knowledgeable (cf. Hodgson 2015; Rosenbaum 2000). Our results are highly suggestive in this sense. What some qualitative research and suggestions by practitioners suggest is that it matters which players take on what position in the market, and also how they internally organise and are externally connected (REFS). How specific markets are institutionally organised and which players exactly have knowledge is likely to affect average deal performance more than high-level or aggregate characterisations about markets. Who has access, directly or indirectly, to what information can also be expected to make a difference.

If and to what extent this is the case, is currently not a feasible topic for research because of a lack of quantitative data. In the short to medium term, qualitative, case study research can offer first-off insights to further substantiate and specify this suggestion. The role of consultancies advising and brokering deals is likely to be an important one.

\section{REFERENCES}

Allen, Franklin, and Douglas Gale, 1994, Financial Innovation and Risk Sharing (MIT Press, Cambridge, Mass.).

Amihud Y, Lev B. 1981. Risk Reduction as a Managerial Motive for Conglomerate Mergers. Bell Journal of Economics 12: 605-617.

Andrade G, Mitchell M, Stafford E. 2001. New Evidence and Perspectives on Mergers. The Journal of Economic Perspectives 15: 103-120.

Barbopoulos, L., K. Paudyal \& G. Pescetto (2011) “Legal systems and gains from crossborder acquisitions” Journal of Business Research. 
Berger PG, Ofek E. 1995. Diversification's Effect on Firm Value. Journal of Financial Economics 37: 39-65.

Bettis, R.A. 1981, Performance differences in related and unrelated diversified firms. Strategic Management Journal 2: 379-393.

Bhide, A., 1990, Reversing corporate diversification, Journal of Applied Corporate Finance 3, 70-81.

Bowman, C., K. Fuller and A. Nain, 2009, Market Valuation and Acquisition Quality: Empirical Evidence, Review of Financial Studies 22(2): 633-679.

Chapman, K., 2003, Cross-Border Mergers/Acquisitions: A review and research agenda, Journal of Economic Geography, 3 (3): 309-334

Child J, Faulkner D, Pitkethly R. 2001. The Management of International Acquisitions. Oxford University Press:

Cho, H.-D. and J.-K. Lee 2003. The developmental path of networking capability of catchup players in Korea’s semiconductor industry. $R \& D$ Management 33: 411-423.

Clark, G. L. (1989) Remaking the maps of corporate capitalism: the arbitrage economy of the 1990s. Environment and Planning A, 21: 997-1000.

Dharwadkar, R., G. George, and P. Brandes. 2000. "Privatization in emerging economies: An agency theory perspective." Academy of Management Review 25, pp. 650-669.

Dong, M., D. Hirshleifer, S. Richardson, and S.H. Teoh, 2006, Does investor misvaluation drive the takeover market?, Journal of Finance 61(2), 725-762.

Freeman, L. C. (1979). Centrality in social networks: Conceptual clarification. Social Networks, 1(3), 215-239.

Fuller K, Netter J, Stegemoller M. 2002. What do Returns to Acquiring Firms Tell Us? Evidence from Firms that Make Many Acquisitions. Journal of Finance 57: 17631793.

Gaughan PA. (2007) Mergers, Acquisitions and Corporate Restructurings. John Wiley and Sons:

Goergen, M., and L. Renneboog, 2004, Shareholder Wealth Effects of European Domestic and Cross-Border Takeover Bids, European Financial Management 10(1), 9-45.

Gozzi JC, Levine R, Schmukler SL. 2008. Patterns of International Capital Raisings.

Haleblian, C.A. Devers, G. McNamara, M.A. Carpenter and R.B. Davison, Taking stock of what we know about mergers and acquisitions: A review and research agenda. Journal of Management, 35 (2009), pp. 469-502.

Harford, J., What drives merger waves, Journal of Financial Economics, 77: 529-560

Hodgson, G.M. Economics and Utopia. London and New York: Routledge, 1999. 
---- (2015) “Markets” in J.B. Davis\& W. Dolfsma (eds.) The Elgar Companion to Social Economics. $2^{\text {nd }}$ Ed. Cheltenham, UK and Northampton MA: Edward Elgar, pp.

Holmström, B., and S.N. Kaplan, 2001, Corporate Governance and Merger Activity in the United States: Making Sense of the 1980s and 1990s, Journal of Economic Perspectives 15, 121-144.

Huang, Y.S. and Walkling, R.A., 1987. Target abnormal returns associated with acquisitions announcements: Payment, acquisitions form, and managerial resistance. Journal of Financial Economics 19, pp. 329-350.

Hubbard, R., Palia, D., 1999. A re-examination of the conglomerate merger wave in the 1960s: an internal capital markets view. Journal of Finance 54, 1131$\} 1152$.

Jensen, M, 1986, Agency Costs of Free Cash Flow, Corporate Finance, and Takeovers, American Economic Review 76 (2), 323-329.

----, 1988, Takeovers: Their Causes and Consequences, Journal of Economic Perspectives 2, 21-48.

---- and William Meckling, 1976, Theory of the firm: Managerial behavior, agency costs, and ownership structure, Journal of Financial Economics 3, 305-360.

Jones GR, Hill CWH. 1988. Transaction Cost Analysis of Strategy-Structure Choice. Strategic Management Journal 9: 159-172.

La Porta, R., F. Lopez-de-Silanes, A. Shleifer and R. Vishny, 2000, Investor Protection and Corporate Governance, Jounal of Financial Economics, 58, 3-27

Lamont OC, Polk C. 2002. Does diversification destroy value? Evidence from the industry shocks. Journal of Financial Economics 63: 51-77.

Lancaster K. 1990. The economics of product variety: a survey. Marketing Science 9: 189206.

Lang L, Stulz RM. 1994. Tobin's Q. Corporate Diversification and Firm Performance. Journal of Political Economy 102: 1248-1280.

Levine R, Schmukler SL. 2006. Internationalization and Stock Market Liquidity. Review of Finance 10: 153-187.

Lichtenberg, F.R., 1992, Industrieal Diversification and Its Consequences for Productivity, Journal of Economic Behaviour and Organization 18, 427-438.

Martynova M, Renneboog L (2008), A Century of Corporate Takeovers: What Have We Learned and Where Do We Stand? Journal of Banking and Finance 32: 2148-2177. McCarthy, K.J., and W.A. Dolfsma, "What's in a Name? Understanding the Language of the Credit Crunch, and of the Role of the Media on Consumer Confidence", Journal of Economic Issues, Vol. XLIII No. 2, June 2009. 
---, ----, (2015) “The Euro, and its Impact on the Number, Size, Performance and Regional Spread of European Mergers and Acquisitions” Regional Studies 49(8): 1407-1422.

----, ----, and U. Weitzel (2016) “The First Global Merger Wave and the Enigma of Chinese Performance" Management \& Organization Review, forthcoming.

Miotti, L., \& F. Sachwald. (2001). Korean multinationals’ strategies and international learning. In: F. Sachwald (Ed.), Going Multinational. The Korean Experience of Direct Investment. London: Routledge.

Moeller SB, Schlingemann FP, Stulz RM. (2005), Wealth Destruction on a Massive Scale?

A Study of Acquiring-Firm Returns in the Recent Merger Wave. Journal of Finance 60: 757-782.

----, ----, and ----. 2004. Firm size and the gains from acquisitions. Journal of Financial Economics 73: 228.

Mueller DC. 1969. A Theory of Conglomerate Mergers. Quarterly Journal of Economics 83: 659 .

Mukherjee TK, Kiymaz H, Baker HK. (2004) Merger Motives and Target Valuation: A Survey of Evidence from CFO's, Journal of Applied Finance 14: 7-24.

Narula, R. 2003. Globalisation and Technology: Interdependence, Innovation Systems and Industrial Policy, Cambridge: Polity Press.

Officer MS. 2007. The Price of Corporate Liquidity: Acquisition Discounts for Unlisted Targets. Journal of Financial Economics 83: 571-598.

Prahalad, C.K, G. Hamel, 1990, The Core Competence of the Corporation, Harvard Business Review, 68(3), pp 79-91

Rajan, R., H. Servaes, L. Zingales, 2000, The Cost of Diversity: The DiversificationDiscount and Inefficient Investment, The Journal of Finance 55(1): 35-80.

Rau, P.R. and T. Vermaelen, 1998, Glamour, value and the post-acquisition performance of acquiring firms, Journal of Financial Economics 49, 223-253.

Ravenscraft, D.J. and F.M. Scherer, 1987, Mergers, Sell-offs and Economic Efficiency, The Brookings Institution, Washington, DC

Rhoades SA. 1983. Power, Empire Building and Mergers. D.C Heath and Co.: Lexington, MA.

Rhodes-Kropf, M., and S. Viswanathan, 2004, Market valuation and Merger Waves, Journal of Finance 59(6), 2685-2718.

Roll R. 1986. The Hubris Hypothesis of Corporate Takeovers. Journal of Business 59: 197216. 
Rosenbaum, E.F. (2000) "What is a Market? On the Methodology of a Contested Concept.” Review of Social Economy 58(4): 455-82.

Saebi, T. and Q. Dong (2009) Strategic motivations for International alliances: the Chinese perspective. Pp78-91 in: W. Dolfsma, G. Duysters, I. Costa (eds). Multinationals and Emerging Economies. Edward Elgar.

Sarkissian S, Schill M. 2008. Are there permanent valuation gains to overseas listing? Evidence from market sequencing and selection. Review of Financial Studies, forthcoming

Scharfstein, D., and J. Stein, 2000. The dark side of internal capital markets: Divisional rentseeking and inefficient investment, Journal of Finance 55, 2537-2564.

Servaes, H., 1991, Tobin's Q and the Gains from Takeovers, Journal of Finance 46 (1), 409-419.

Shin H. and R. Stulz (1998) “Are Internal Capital Markets Efficient?” Quarterly Journal of Economics 113 (2), 531-552.

----, and ----. 1991, Takeovers in the '60s and the '80s: Evidence and Implications, Strategic Management Journal 12: 51-59.

----, and ----. 2003, Stock market driven acquisitions, Journal of Financial Economics 70, 295-311.

----, and ----. 1989, Management entrenchment: The case of manager-specific investments, Journal of Financial Economics. 25, 123-140.

Travlos, N.G., 1987, Corporate takeover bids, methods of payment, and acquiring firms’ stock returns, Journal of Finance 42, 943- 963.

Weston FJ, Mitchell ML, Mulherin HJ. (2004) Takeovers, Restructuring and Corporate Governance. Pearson Prentice Hall: Upple Saddle River, New Jersey.

Weston, J.F and S.K. Mansinghka, 1971, Tests of Efficiency Performance in Conglomerate Firms, Journal of Finance, XXVI, pp 919-936

Williamson OE. 1967. Hierarchical Control and Optimum Firm Size. Journal of Political Economy 75: 123-138.

Young, M., Peng, M. W., Ahlstrom, D., Bruton, G. D., \& Jiang, Y. 2008. Corporate governance in emerging economies: A review of the principal-principal perspective. Journal of Management Studies, 45: 196-220.

ZuidHOF, P.-W. (2014) “Thinking Like an Economist: The Neoliberal Politics of the Economics Textbook” REVIEW OF SOCIAL ECONOMY 72(2): 157-185. 
Table 1 - The Geographic Spread of the Sample

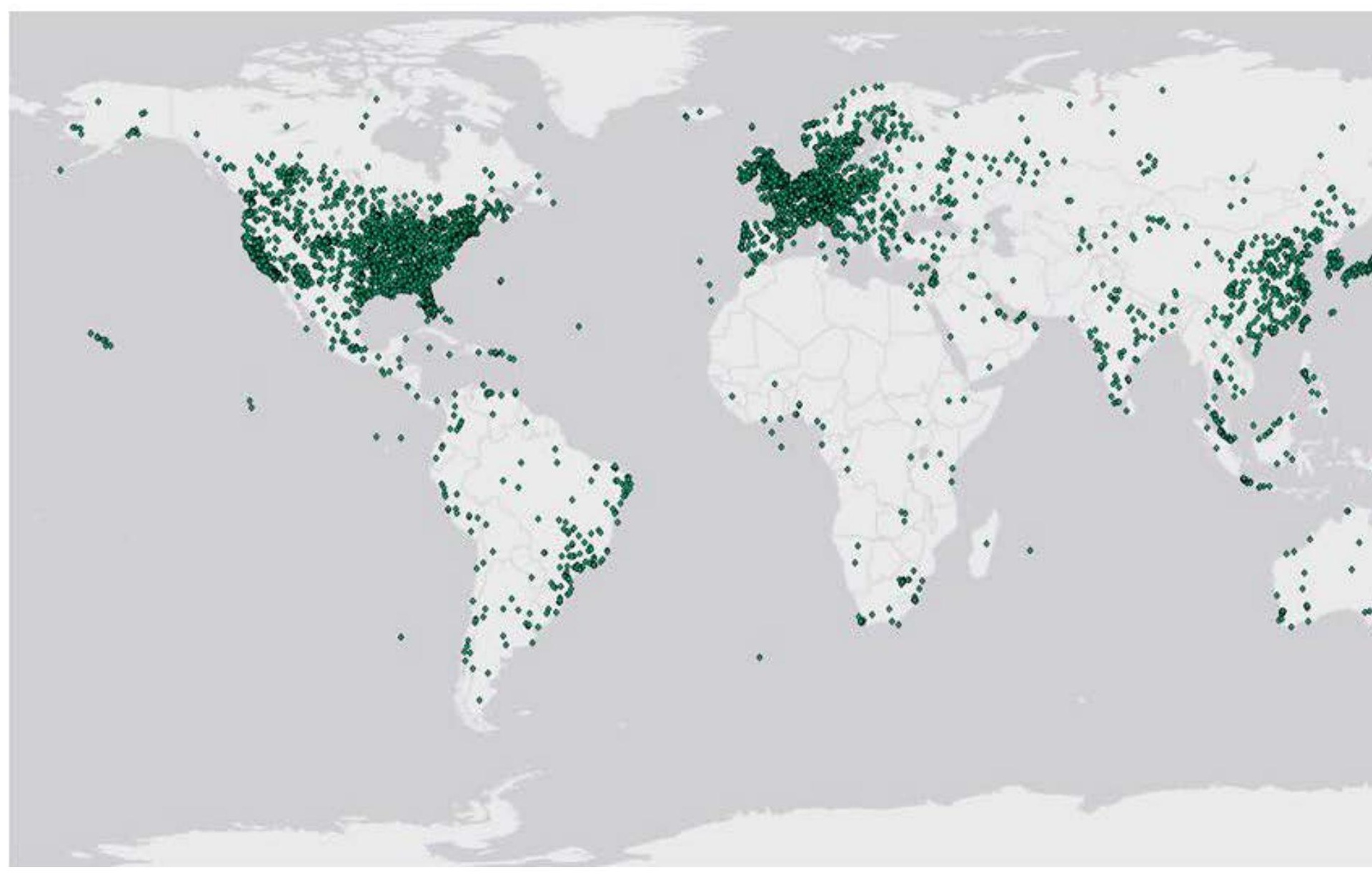


Table 1 - Descriptive Statistics

\begin{tabular}{|c|c|c|c|c|c|c|c|c|c|c|c|c|c|c|c|c|c|}
\hline & & Mean & S.D. & Min & Max & 1 & 2 & -3 & 4 & 5 & 6 & 7 & 8 & 9 & 10 & 11 & 12 \\
\hline 1 & CAR1 & 0.01 & 0.06 & -0.16 & 0.24 & 1.00 & & & & & & & & & & & \\
\hline 2 & CAR2 & 0.01 & 0.14 & -0.40 & 0.51 & $\begin{array}{l}0.43 \\
0.00\end{array}$ & 1.00 & & & & & & & & & & \\
\hline 3 & CAR5 & 0.01 & 0.08 & -0.22 & 0.31 & $\begin{array}{l}0.68 \\
0.00\end{array}$ & $\begin{array}{l}0.60 \\
0.00\end{array}$ & 1.00 & & & & & & & & & \\
\hline 4 & CAR20 & 0.01 & 0.14 & -0.40 & 0.51 & $\begin{array}{l}0.43 \\
0.00\end{array}$ & $\begin{array}{c}1.00 \\
-1.00\end{array}$ & $\begin{array}{l}0.60 \\
0.00\end{array}$ & 1.00 & & & & & & & & \\
\hline 5 & Degree Centrality & 151.28 & 104.12 & 1.00 & 379.00 & $\begin{array}{c}-0.03 \\
0.00\end{array}$ & $\begin{array}{l}-0.01 \\
-0.09\end{array}$ & $\begin{array}{c}-0.03 \\
0.00\end{array}$ & $\begin{array}{l}-0.01 \\
-0.09\end{array}$ & 1.00 & & & & & & & \\
\hline 6 & Betweeness Centrality & 0.01 & 0.01 & 0.00 & 0.04 & $\begin{array}{c}-0.02 \\
0.00\end{array}$ & $\begin{array}{l}-0.01 \\
-0.21\end{array}$ & $\begin{array}{l}-0.02 \\
-0.01\end{array}$ & $\begin{array}{l}-0.01 \\
-0.21\end{array}$ & $\begin{array}{l}0.86 \\
0.00\end{array}$ & 1.00 & & & & & & \\
\hline 7 & Percent Acquired & 97.20 & 9.44 & 51.00 & 100.00 & $\begin{array}{c}0.00 \\
-0.65\end{array}$ & $\begin{array}{c}0.01 \\
-0.07\end{array}$ & $\begin{array}{c}0.01 \\
-0.06\end{array}$ & $\begin{array}{c}0.01 \\
-0.07\end{array}$ & $\begin{array}{l}0.05 \\
0.00\end{array}$ & $\begin{array}{c}-0.06 \\
0.00\end{array}$ & 1.00 & & & & & \\
\hline 8 & Acquirers Financial Slack (Log) & -2.90 & 0.99 & -11.01 & 3.44 & $\begin{array}{c}0.00 \\
-0.62\end{array}$ & $\begin{array}{l}-0.01 \\
-0.47\end{array}$ & $\begin{array}{c}0.00 \\
-0.77\end{array}$ & $\begin{array}{l}-0.01 \\
-0.47\end{array}$ & $\begin{array}{c}0.00 \\
-0.90\end{array}$ & $\begin{array}{c}-0.09 \\
0.00\end{array}$ & $\begin{array}{l}0.08 \\
0.00\end{array}$ & 1.00 & & & & \\
\hline 9 & Acquirers Prior Performance (Log) & 1.82 & 0.84 & -4.61 & 6.06 & $\begin{array}{l}-0.01 \\
-0.15\end{array}$ & $\begin{array}{l}-0.02 \\
-0.03\end{array}$ & $\begin{array}{l}-0.01 \\
-0.25\end{array}$ & $\begin{array}{l}-0.02 \\
-0.03\end{array}$ & $\begin{array}{l}-0.02 \\
-0.05\end{array}$ & $\begin{array}{c}-0.09 \\
0.00\end{array}$ & $\begin{array}{l}0.08 \\
0.00\end{array}$ & $\begin{array}{l}0.81 \\
0.00\end{array}$ & 1.00 & & & \\
\hline 10 & Acquirers Market-to-Book Ratio & 0.00 & 0.15 & -3.33 & 19.15 & $\begin{array}{c}0.00 \\
-0.54\end{array}$ & $\begin{array}{l}-0.01 \\
-0.32\end{array}$ & $\begin{array}{l}-0.01 \\
-0.45\end{array}$ & $\begin{array}{l}-0.01 \\
-0.32\end{array}$ & $\begin{array}{c}0.00 \\
-0.54\end{array}$ & $\begin{array}{c}0.00 \\
-0.56\end{array}$ & $\begin{array}{c}0.00 \\
-0.69\end{array}$ & $\begin{array}{c}0.01 \\
-0.24\end{array}$ & $\begin{array}{c}0.01 \\
-0.32\end{array}$ & 1.00 & & \\
\hline 11 & Related Acquisition & 0.35 & 0.48 & 0.00 & 1.00 & $\begin{array}{c}0.00 \\
-0.62\end{array}$ & $\begin{array}{l}-0.01 \\
-0.25\end{array}$ & $\begin{array}{l}-0.01 \\
-0.11\end{array}$ & $\begin{array}{l}-0.01 \\
-0.25\end{array}$ & $\begin{array}{l}-0.01 \\
-0.20\end{array}$ & $\begin{array}{c}-0.02 \\
0.00\end{array}$ & $\begin{array}{c}0.01 \\
-0.07\end{array}$ & $\begin{array}{c}-0.03 \\
0.00\end{array}$ & $\begin{array}{c}-0.03 \\
0.00\end{array}$ & $\begin{array}{c}0.00 \\
-0.95\end{array}$ & 1.00 & \\
\hline 12 & Cross Border Acquisition & 0.26 & 0.44 & 0.00 & 1.00 & $\begin{array}{c}0.01 \\
-0.35\end{array}$ & $\begin{array}{c}0.00 \\
-0.82\end{array}$ & $\begin{array}{c}0.00 \\
-0.85\end{array}$ & $\begin{array}{c}0.00 \\
-0.82\end{array}$ & $\begin{array}{c}-0.09 \\
0.00\end{array}$ & $\begin{array}{c}0.01 \\
-0.26\end{array}$ & $\begin{array}{c}-0.09 \\
0.00\end{array}$ & $\begin{array}{c}0.00 \\
-0.84\end{array}$ & $\begin{array}{c}0.02 \\
-0.06\end{array}$ & $\begin{array}{l}-0.01 \\
-0.46\end{array}$ & $\begin{array}{l}-0.01 \\
-0.10\end{array}$ & 1.00 \\
\hline
\end{tabular}


Table 2 - Betweenness Centrality and Performance

\begin{tabular}{|c|c|c|c|c|}
\hline VARIABLES & $\begin{array}{c}(1) \\
\text { wCAR1 }\end{array}$ & $\begin{array}{c}(2) \\
\text { wCAR20 }\end{array}$ & $\begin{array}{c}\text { (3) } \\
\text { wCAR5 }\end{array}$ & $\begin{array}{c}(4) \\
\text { wCAR20 }\end{array}$ \\
\hline Betweeness Centrality & $\begin{array}{c}-0.10 * * * \\
(-2.668)\end{array}$ & $\begin{array}{c}-0.17 * * * \\
(-1.869)\end{array}$ & $\begin{array}{c}-0.11 * * * \\
(-2.143)\end{array}$ & $\begin{array}{l}-0.17 * * \\
(-1.869)\end{array}$ \\
\hline Percent Acquired & $\begin{array}{c}0.00 \\
(0.275)\end{array}$ & $\begin{array}{c}0.00 \\
(1.067)\end{array}$ & $\begin{array}{c}0.00 \\
(1.260)\end{array}$ & $\begin{array}{c}0.00 \\
(1.067)\end{array}$ \\
\hline Acquirers Financial Slack (Log) & $\begin{array}{c}0.00 \\
(1.385)\end{array}$ & $\begin{array}{c}0.00 \\
(0.281)\end{array}$ & $\begin{array}{c}0.00 \\
(0.325)\end{array}$ & $\begin{array}{c}0.00 \\
(0.281)\end{array}$ \\
\hline Acquirers Prior Performance (Log) & $\begin{array}{c}-0.00 \\
(-1.559)\end{array}$ & $\begin{array}{c}-0.00 \\
(-1.053)\end{array}$ & $\begin{array}{c}-0.00 \\
(-0.417)\end{array}$ & $\begin{array}{c}-0.00 \\
(-1.053)\end{array}$ \\
\hline Acquirers Market-to-Book Ratio & $\begin{array}{c}-0.00 \\
(-0.667)\end{array}$ & $\begin{array}{c}-0.01 \\
(-1.406)\end{array}$ & $\begin{array}{c}-0.00 \\
(-1.001)\end{array}$ & $\begin{array}{c}-0.01 \\
(-1.406)\end{array}$ \\
\hline Related Acquisition & $\begin{array}{c}0.00 \\
(0.133)\end{array}$ & $\begin{array}{c}0.00 \\
(0.774)\end{array}$ & $\begin{array}{c}-0.00 \\
(-0.204)\end{array}$ & $\begin{array}{c}0.00 \\
(0.774)\end{array}$ \\
\hline Cross Border Acquisition & $\begin{array}{c}0.00 * \\
(1.664)\end{array}$ & $\begin{array}{c}0.00 \\
(0.395)\end{array}$ & $\begin{array}{c}0.00 \\
(0.653)\end{array}$ & $\begin{array}{c}0.00 \\
(0.395)\end{array}$ \\
\hline Year Dummies & Yes & Yes & Yes & Yes \\
\hline Acquirer Industry Dummy & Yes & Yes & Yes & Yes \\
\hline Target Industry Dummy & Yes & Yes & Yes & Yes \\
\hline Constant & $\begin{array}{c}-0.01 \\
(-0.695)\end{array}$ & $\begin{array}{c}0.04 \\
(0.927)\end{array}$ & $\begin{array}{c}-0.00 \\
(-0.026)\end{array}$ & $\begin{array}{c}0.04 \\
(0.927)\end{array}$ \\
\hline $\begin{array}{l}\text { Observations } \\
\text { Adjusted R-squared } \\
\text { F }\end{array}$ & $\begin{array}{c}13,661 \\
0.09 \\
2.145\end{array}$ & $\begin{array}{c}13,661 \\
0.05 \\
1.640\end{array}$ & $\begin{array}{c}13,661 \\
0.03 \\
1.438\end{array}$ & $\begin{array}{c}13,661 \\
0.05 \\
1.640\end{array}$ \\
\hline
\end{tabular}

t-statistics in parentheses

*** $\mathrm{p}<0.01, * * \mathrm{p}<0.05, * \mathrm{p}<0.1$ 
Table 3 - Degree Centrality and Performance

\begin{tabular}{lcccc}
\hline & $(5)$ & $(6)$ & $(7)$ & $(8)$ \\
VARIABLES & wCAR1 & wCAR20 & wCAR5 & wCAR20 \\
\hline \multirow{2}{*}{ Degree Centrality } & $-0.00 * * *$ & $-0.00 * * *$ & $-0.00 * * *$ & $-0.00 * *$ \\
& $(-4.307)$ & $(-1.487)$ & $(-3.199)$ & $(-1.487)$ \\
Percent Acquired & 0.00 & 0.00 & 0.00 & 0.00 \\
& $(0.567)$ & $(1.227)$ & $(1.489)$ & $(1.227)$ \\
Acquirers Financial Slack (Log) & 0.00 & 0.00 & 0.00 & 0.00 \\
& $(1.451)$ & $(0.320)$ & $(0.376)$ & $(0.320)$ \\
Acquirers Prior Performance (Log) & -0.00 & -0.00 & -0.00 & -0.00 \\
& $(-1.531)$ & $(-0.997)$ & $(-0.386)$ & $(-0.997)$ \\
Acquirers Market-to-Book Ratio & -0.00 & -0.01 & -0.00 & -0.01 \\
& $(-0.679)$ & $(-1.404)$ & $(-1.008)$ & $(-1.404)$ \\
Related Acquisition & 0.00 & 0.00 & -0.00 & 0.00 \\
& $(0.187)$ & $(0.818)$ & $(-0.159)$ & $(0.818)$ \\
Cross Border Acquisition & 0.00 & 0.00 & 0.00 & 0.00 \\
& $(1.332)$ & $(0.303)$ & $(0.413)$ & $(0.303)$ \\
Year Dummies & Yes & Yes & Yes & Yes \\
Acquirer Industry Dummy & & & & Yes \\
Target Industry Dummy & Yes & Yes & Yes & Yes \\
Constant & & & & \\
& Yes & Yes & Yes & 0.04 \\
Observations & & & -0.00 & $(0.886)$ \\
Fdjusted R-squared & -0.01 & 0.04 & $(-0.065)$ & 13,661 \\
\hline
\end{tabular}

t-statistics in parentheses

*** $\mathrm{p}<0.01,{ }^{* *} \mathrm{p}<0.05,{ }^{*} \mathrm{p}<0.1$ 